\title{
RUBIDIUM-STRONTIUM AGE DETERMINATIONS ON SOUTH AFRICAN KIMBERLITE PIPES
}

\author{
D. R. Barrett and H.L. Allsopp \\ Bernard Price Institute of Geophysical Research, \\ University of the Witwatersrand, Johannesburg.
}

Although kimberlite pipes are common in South Africa relatively few isotopic age measurements have been made on samples from these pipes. Lovering and Richards (1964) reported $\mathrm{K}-\mathrm{Ar}$ measurements on mica and pyroxene from eclogite inclusions in the Roberts Victor pipe but obtained inconsistent results. Allsopp et al. (1969) reported $\mathrm{Rb}-\mathrm{Sr}$ ages on three mica samples: two Roberts Victor eclogite micas indicated an age of $105 \pm 20 \mathrm{~m} . \mathrm{y}$. , ana one Du Toitspan peridotite mica indicated an age of approximately $80 \mathrm{~m} \cdot \mathrm{y}$. Allsopp et al. (1967) used $\mathrm{Rb}-\mathrm{Sr}$ bioti.te measurements to establish a definite minimum age of $1115 \pm 15$ m.y. for the Premier pipe, and galena data suggested that the pipe might be as old as $1750 \pm 100 \mathrm{~m} \cdot \mathrm{y}$.

The present study was undertaken to establish to what extent reliable ages could be obtained by the $\mathrm{Rb}-\mathrm{Sr}$ isochron method on phlogopite micas from kimberlite and its associated inclusions, and to establish whether significant age differences exist between various pipes. The Table below summarises the results obtained from nine different kimberlite pipes.

Primary mica (i.e. mica crystallised prior to pipe emplacement) would be expected to yield the age of pipe emplacement since temperatures in the source region are almost certainly high enough to maintain isotopic equilibrium prior to that time. Secondary mica, if associated with pipe emplacement, would be expected to yield the same age. In both cases, however, variations in the primary $\mathrm{Sr} 87 / \mathrm{Sr} 86$ ratio might occur, and samples of the two types, and also micas from different types of inclusion, may not define a single linear isochron. As a test of this the Wesselton pipe was subjected to detailed study, micas from the kimberlite groundmass, from peridotite nodules and from phlogopite nodules all being studied. Two significantly different isochrons (ages $11.8 \pm 6$ and $78 \pm 3$ m.y.) were obtained, one defined by the phlogopite nodules and the other by the other two types. (A minority of samples were rejected due to the data lying more than five standard deviations from the mean line, and the same procedure was adopted with the data from other pipes. Such scatter could be due to experimental error, but it is more likely to be the result of post-emplacement alteration.) The most significant result is that a linear isochron was obtained for samples of a given type, and according to isochron theory, it is most probable that the indicated ages are valid.

As noted above the micas from the phlogopite nodules indicate a different age from those from peridotite nodules and from kimberlite groundmass. Radiogenic Sr retention in the presumed primary phlogopite nodules is one possible explanation of this anomaly. This is considered unlikely since in such a case the degree of retention would vary 
depending on sample size and other factors, thereby giving rise to a nonlinear isochron; in fact an excellent isochron was obtained for the phlogopite nodules. A simpler explanation is that there wer $\epsilon$ different periods of kimberlite intrusion in the Wesselton pipe, with the phlogopite nodules being largely or entirely confined to one particular intrusion, and the peridotite nodules to another. Observations in the mine clearly show that there have been different periods of intrusion, but no information is available as to the distribution of different types of nodule. No definite conclusion can be reached on the fundamental question of whether the isochron method yield's reliable ages for kimberlites, and the distribution of nodules at Wesselton should be investigated with a view to clarifying this issue.

Reference to the table shows that ages in the range 147 to $78 \mathrm{~m} \cdot \mathrm{y}$. are indicated for all pipes apart from Premier. The prima facie evidence, therefore, is that there has been an extended period of kimberlite formation during Jurassic to lower Cretaceous times, with different intrusions sometimies following earlier ones up the same pipe.

A completely different approach was adopted in the dating of the Premier pipe. In this pipe at least four types of kimberlite have been mapped, and a sequence of intrusions has been suggested. The situation is, however, complicated by the intrusion of a diabase sill that post-dates both the pipe and the country rock. The heating effect of the sill would be expected to "re-set" the ages of micas situated close to the sill, and to affect micas further from the sill to a lesser extent. Local variations in the temperature distribution (associated with minor diabase intrusions) and the formation of secondary mica as a direct result of diabase-induced metamorphism coula be expected to effect departures from the simple pattern indicated. Nevertheless six samples of Type 1 kimberlite yield results of the expected pattern (see Figure); one aditional sample is discrepant and this sample is from an area in which minor intrusions have been observed. From these data $i t$ is concluded that the age of the Type 1 kimberlite is close to $1250 \mathrm{~m} \bullet \mathrm{y}$. Data for the Type 4 kimberlite is widely scattered, with ages both older and younger than $1250 \mathrm{~m} . \mathrm{y}$. being indicated. No definite conclusions can be reached, but it is possible that the Type 4 is a mixture of the Types 1,2 and 3 . Of these Type 2 is considered to be the oldest and Type 3 the youngest; mixture of these could account for the observed scatter, and very tentatively ages of $\sim 1400 \mathrm{~m} \cdot \mathrm{y}$. and $\sim 1200 \mathrm{~m} \cdot \mathrm{y}$. are assigned to Types 2 and 3 respectively.

\section{REFERENCES}

Lovering, J.F., and Richards, J.R. J. Geophys. Res. 69 (1964) 4895.

Allsopp, H.L., Nicolaysen, L.O. and Hahn-Weinheimer, P. Earth \& Plan. Sci. Letters, 5 (1969) 231.

Allsopp, H.L., Burger, A.J., and van Zyl, C. Earth \& Plan. Sci. Letters, 3 (1967) 161. 
Type

Wesselton peridotite nodules

Wesselton groundmass

Wesselton phlogopite nodules

Kimberley area (excl. Wesselton) peridotite nodules

Roberts Victor eclogite nodules

Monastery groundmass

Gross Brukkaros groundmass

Swartruggens groundmass

Premier groundmass Type 1

$$
\begin{aligned}
& \text { Age (m.y.) } \mathrm{Sr}^{87} / \mathrm{Sr}^{86} \text { 。 } \\
& 77 \pm 20.7101 \pm .0014 \\
& 80 \pm 40.7074 \pm .0016 \\
& 118 \pm 60.7096 \pm .0005 \\
& 89 \pm 20.7073 \pm .0007 \\
& 126 \pm 40.7082 \pm .0012 \\
& 90 \pm 3 \quad 0.7050 \pm .0011 \\
& \text { ح84 } 20.7041 \\
& 147 \pm 20.7067 \pm .0009 \\
& \text { 21250* }
\end{aligned}
$$

* Note that both older and younger ages are indicated by Type 4.

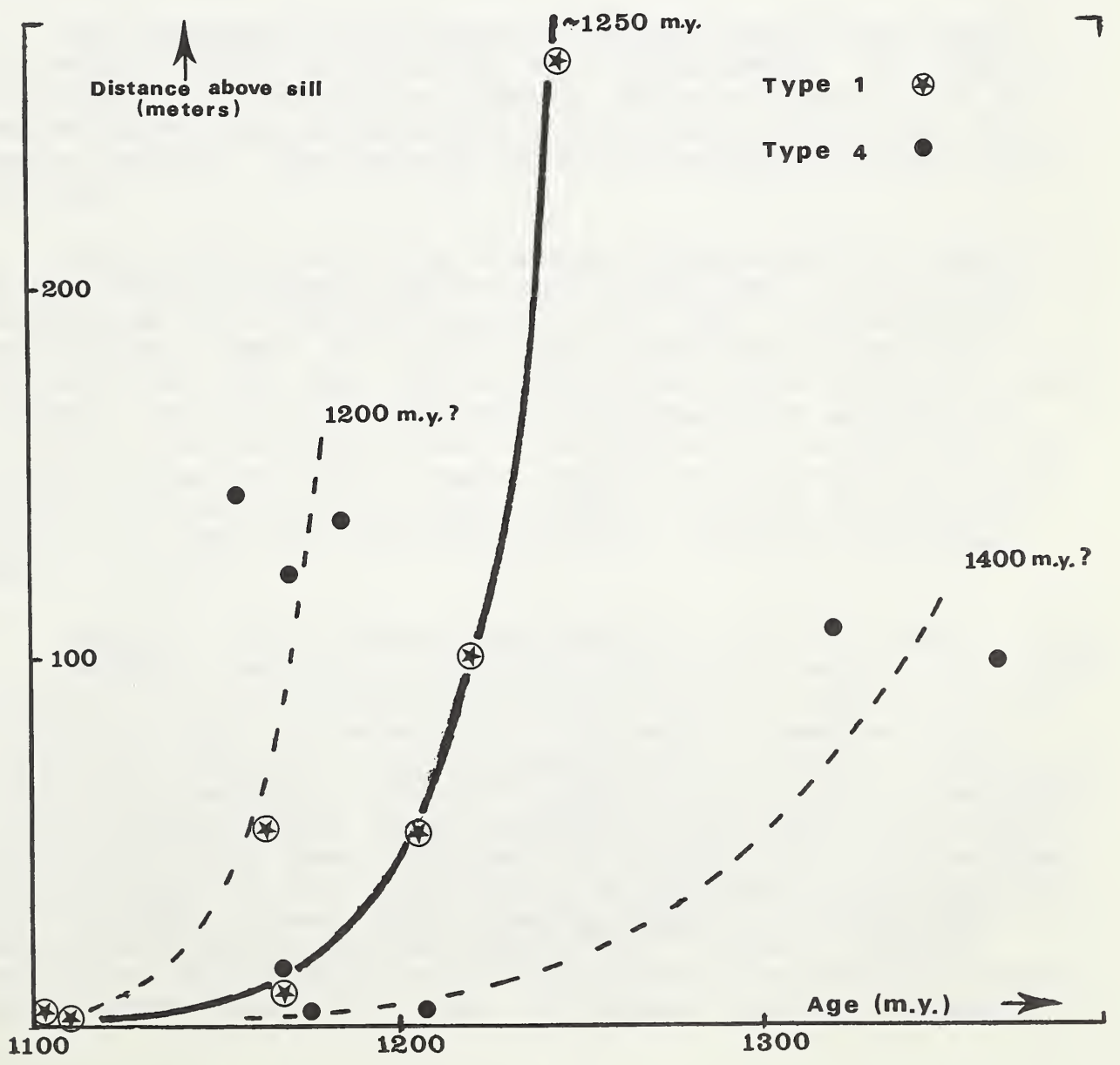

Barrett and Allsopp 